\title{
Adaptations in SCOR Based Performance Metrics of Airline Catering Supply Chain during COVID-19 Pandemic
}

\author{
Dhaarsan Rajaratnam iD, Funlade Sunmola iD \\ University of Hertfordshire (United Kingdom) \\ dhaarsan@gmail.com,f.sunmola@herts.ac.uk
}

Received: May 2021

Accepted: August 2021

\begin{abstract}
:
Purpose: There is the propensity of airline catering supply chains to adapt their performance measures in order to meet desired service level due to the challenges of the COVID-19 pandemic. The aim of this paper is to develop a set of metrics for airline catering organisations and explore the choices of SCOR based performance metrics during the COVID-19 pandemic.

Design/methodology/approach: Case study approach involving an airline catering supply chain organisation is adopted in this research. The SCOR framework is applied in the context of the case study supply chain to develop a performance metrics model for the chain. The performance metrics model is analysed and validated by a set of experts in the case study organisation. The experts are formed into a focus group. The performance metrics were prioritised using MoSCoW method based on the experience of the focus group participants on COVID-19 challenges.
\end{abstract}

Findings: A hierarchical performance measure framework is proposed, and a set of 55 metrics from the SCOR framework is identified and validated for airline catering supply chains. MoSCoW based prioritisation of the metrics by the focus group participants results in 7 Level-1 SCOR metrics and 13 Levels 2 \& 3 SCOR metrics been considered as necessary to better mitigate COVID-19 pandemic challenges.

Research limitations/implications: This research is based on a single case study and a small number of participants, which limits the generalisability of the results.

Practical implications: With the development of performance metrics and the prioritisation presented in this paper, airline catering organisations can monitor their catering logistics performance and use techniques such as MoSCoW to decide performance measures priorities in situations such as the COVID-19 pandemic.

Originality/value: The work contributes to measuring performance in the airline catering supply chain and the need for considering adapting performance metrics using techniques such as MoSCoW, during challenging periods as in the COVID-19 pandemic.

Keywords: airline catering supply chain, SCOR, performance metrics, MoSCoW

\section{To cite this article:}

Rajaratnam, D., \& Sunmola, F. (2021). Adaptations in SCOR based performance metrics of airline catering supply chain during COVID-19 pandemic. Journal of Industrial Engineering and Management, 14(4), 808-829. https://doi.org/10.3926/jiem.3592 


\section{Introduction}

Airline catering businesses have challenges in implementing an effective supply chain, particularly under high uncertainty. In meeting service level objectives, it is vital for airline businesses to embed appropriate performance measurement strategies in their supply chain processes. Several models and frameworks have been developed for understanding and benchmarking supply chain practices. Most common is the SCOR model. Supply chain partners commonly use the model due to the measurable characteristics and actionable outcomes included in the framework to improve supply chain performance (Lu, Goh \& De Souza, 2016).

The COVID-19 pandemic has threatened and caused critical concern for the global supply chains, including those of airline catering businesses. This unprecedented challenge has deeply impacted the business environment and health care systems around the world. As the supply chain is the backbone of many production and service operations, academic researchers and practitioners have been challenged to explore the strategies to mitigate the imminent disruptions in both upstream and downstream supply chains. Unique supply chain disruptions like the COVID-19 outbreak are low-frequency, high-impact events that cause failure in one or more supply chain nodes and can lead to the unavailability of services or goods (Kumar, Basu \& Avittathur, 2018). Disruptive events provide an opportunity to learn from their effects, and learning from the COVID-19 pandemic can improve future performance management and decision-making during supply chain disruptions (Remko, 2020).

Airline passenger traffic has usually increased year on year and ready to stay in this rising trend. According to an analysis done by IATA (The International Air Transport Association), the number of airline passengers could double up and reach 8.2 billion in 2037 (IATA, 2018). However, the airline industry is almost grounded by COVID-19, and the recovery has slowed in most markets due to travel restrictions (Albers \& Rundshagen, 2020). It is recognised as the most significant decline since World War II. This has a significant impact on airline catering service organisations, and their operations have been severely affected. COVID-19 crisis is longer and deeper than anyone would have expected. A recent press release from IATA estimated a net airline industry loss of $\$ 126.4$ billion in 2020. IATA represents 290 airlines, including $82 \%$ of worldwide air traffic. It recognised that the losses would decrease from 2020, but the pain of the crisis will increase (IATA, 2021).

Airline catering organisations must adapt the aspects of supply chain performance measures concerning emergencies such as the COVID-19 pandemic according to the dynamic of the aviation environment, business context, and the catering service requirements. The disruptive events have a significant impact on financial and operational performance in the airline catering supply chain. The challenge for airline catering organisations is to improve or develop new performance measures to warn malfunction risks and better support decision-making in situations like the COVID-19 pandemic. Like many other enterprises, airline catering organisations also need to address questions such as "How to effectively use the supply chain performance measures in airline catering service during unexpected significant disruptions?" and "What performance metrics should be considered to measure airline catering supply chain performance during disruptive situations like COVID-19 pandemic?".

In an example case, a large airline catering supply chain in the United Kingdom is interested in exploring the choice of their performance metrics during the COVID-19 pandemic. The supply chain has a set of performance measures in place and would like to adopt the SCOR framework in order to improve their logistics service performance and the effectiveness of their catering operations. This is the focus of the research reported in this paper, and the large airline catering supply chain is used as a case study. The SCOR model version 12 is adapted to develop supply chain performance measures for the airline catering supply chain. This paper is one of the few studies on the implementation of the SCOR model for the airline catering supply chain, an emerging and important research area in the travel, tourism and aviation industry. As part of the research reported in this paper, we worked with the case study organisation to develop performance metrics for the organisation's airline catering supply chain and analysed the performance metrics considerations of the case study organisation during the COVID-19 pandemic.

Following this introduction, the remainder of this paper contains six sections. Section 2 provides a brief overview of the airline catering supply chain, supply chain performance measures, and COVID-19 challenges in the supply chain. The SCOR framework and its structure is introduced in Section 3 and the research methodology adopted in 
this paper is presented in Section 4. Section 5 presents the airline catering SCOR model developed in this research and describes the adaptation and development of performance metrics for the airline catering supply chain used as the case study in this paper. The case study results are presented in Section 6, along with discussion of the results. The paper concludes in Section 7 and offers recommendations for future work.

\section{Background and Related Work}

\subsection{Airline Catering Supply Chain}

The fundamental role of the global airline industry in the world economy is demonstrated by the fact that aviation creates 65.5 million jobs worldwide, offers $\$ 2.7$ trillion in business activities and $35 \%$ of world trade value generated by air travel (Amankwah-Amoah, 2020). The airline catering industry is also one of the large industries in the world. The market's total size has exceeded 17.8 billion U.S. dollars in 2019 (Pulidindi \& Mukherjee, 2020) and is estimated to reach around 25 billion U.S. dollars in 2026 (Mazareanu, 2020). In the airline catering market environment, the airline catering industry is not only preparing those meals, but they are also responsible for the complete airline catering solution, including provisioning supply chain and logistics services (King, 2001). This involves managing complex processes such as ordering products from the supplier, physical handling, managing inventory, distribution and final delivery of goods to the aircraft (Jones, 2007). Changes like passenger movements, flight schedule changes and aircraft changes happen in the airline business in real-time. Therefore, catering service providers need to decide on an immediate response within a short time frame for a quicker catering service delivered to the airline. Key Performance Indicators (KPIs) are essential in the service contracts between airlines and caterers. Accuracy of load, on-time delivery, value for money, hygiene and food safety, responsiveness, and overall operational performance are common KPIs for airline catering service.

The airline catering supply chain is a complex supply chain. A wide range of materials is loaded into each flight. These include meals, beverages to toiletries and earphones. Large aircrafts such as A380 or 787 are required to load thousands of items (Hovora, 2001). From a simple beverage for the economy class passenger in a short-haul domestic flight to a delicious full-course meal for the first-class passenger on a long haul flight, airline catering industries offer a wide range of meals. The Airline catering supply chain is commonly composed of five major parties, airline, caterer, supplier, logistics provider and passengers, as shown in Figure 1.

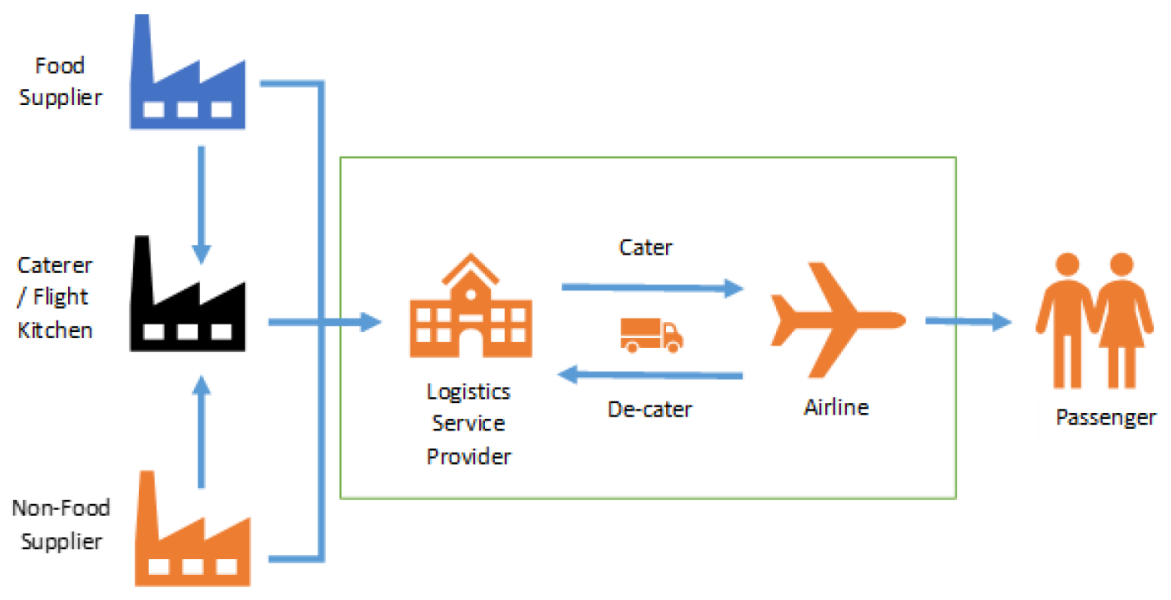

Figure 1. Airline Catering Supply Chain

The airline business is increasingly very competitive. Most airlines are trying to achieve a considerable portion of cost savings through the opportunities in the airline catering supply chain. The cost efficiency is obtained collaboratively by each stakeholder. Each stakeholder in the supply chain has a specific responsibility. Airlines are responsible for menu design and onboard logistics planning. Caterers cook meals and assemble them in specific airline containers. Suppliers supply all materials, such as ancillaries, tray set components and snacks items. Logistics providers play a crucial role in this supply chain. They manage all airline equipment, consumable and rotable 
products. They are responsible for transporting meals, bars and equipment from the kitchen or assembly centres to the airside and load them into the aircraft. They also bring them back to the facility from the returned flights. Airline catering operations consist of $80 \%$ logistics activities and $20 \%$ cooking processes (Sundarakani, Abdul-Razzak \& Manikandan, 2018). The logistics service provider needs to understand the catering requirements, main objectives, challenges and trends experienced by airline customers. This enables logistics companies to develop solutions that continually add value to the customer and improve their operational performance. Accurately receiving the catering orders from airlines and efficiently processing them is critical in the airline catering logistics operation. Airline catering logistics providers have complete responsibility for the overall logistics processes and the quality of catering service.

\subsection{Supply Chain Performance Measures}

Supply chain is formed by different entities that are linked together by the flows of products, information, and finance. It facilitates a product that reaches the customer through transforming raw materials into a finished product and distribution processes. Supply chain is the backbone of businesses seeking growth and profitability. Therefore, evaluating the effectiveness of supply chain management strategies to improve its performance has become increasingly important. It is important to continually improve on approaches for measuring the performance of an organisation's supply chain. The supply chain performance measurement system consists of metrics that help organisations quantify the effectiveness of their supply chain. The metrics provide meaningful information about historical events to the management with a view to helping them make informed decisions regarding future performance.

The performance of the supply chain is critical to the proper functioning of economies. Failures can lead to bottlenecks that have a negative impact on productivity and economic growth (Salvatore, 2020). Nevertheless, Supply chains have many dimensions, and their coordinated operation is critical to the timely and smooth delivery of products to customers and contribution to businesses (Elekdag, Muir \& Wu, 2015). While understanding the performance of the supply chain is not new, supply chain performance attributes such as reliability, responsiveness and agility have drawn renewed attention following the recent COVID-19 crisis. Governments around the world have moved with urgency to ensure sufficient supplies of medical equipment, and vaccines, avoid unnecessary transportation disruption and guarantee consistent food supplies.

The literature on supply chain performance measures has evolved. Many authors have proposed many frameworks that shift the focus from performance measures to performance measurement systems. Many studies have been conducted on supply chain performance assessment through case studies, surveys, and literature reviews. The studies recommend various methods to evaluate supply chain performance, including conceptual framework, quantitative models, and tools to select appropriate metrics and reveal a set of operational and financial metrics essential for monitoring and assessing the supply chain performance (Lu et al., 2016). Performance measurement frameworks typically group these metrics under different competitive dimensions such as sustainability, responsiveness, effectiveness, flexibility and define within multiple perspectives like the customer, operations, finance, information technology, and environment (Adivar, Hüseyinoğlu \& Christopher, 2019).

A number of recent research studies focus on quantitative models to support the need for automated decision-making processes. These models, for example, apply artificial intelligence (AI) techniques to predict supply chain and logistics performance. Lima-Junior and Carpinetti (2020) proposed a performance prediction system based on the SCOR model and artificial neural networks. Sustainability management is vital to reach supply chain objectives and logistics service effectiveness. It is critical to incorporate sustainability measures to determine sustainability performance in the supply chain. Various sustainability measurement approaches are being used in different industries. They address the environmental issues to a considerable degree (Ahi \& Searcy, 2015). It has been recognised that incorporating sustainability requirements into the standard supply chain performance model is challenging. Qorri, Mujkić and Kraslawski (2018) developed a conceptual framework for sustainability performance measurement by reviewing 104 papers. They found that the Fuzzy logic technique, DEA (Data Envelopment Analysis), AHP (Analytical Hierarchy Process), Balance Scorecard, and Life Cycle Assessment are the most commonly used methods. The SCOR model is applied as the structural basis in most of these techniques or is 
often used in combination with other performance measure methods (Sellitto, Pereira, Borchardt, Da Silva \& Viegas, 2015).

In this paper, desirable performance metric characteristics for airline catering supply chains have been explored and derived from a review of the literature, SCOR framework, and airline catering business documents and reports to select a range of performance metrics for the airline catering supply chain. Some characteristics of good performance metrics related to supply chain management, with reference to airline catering supply chains, are listed in Table 1.

\begin{tabular}{|c|c|l|}
\hline Item & Characteristic & \multicolumn{1}{|c|}{ Description } \\
\hline 1 & Accurate & $\begin{array}{l}\text { Able to project/calculate performance measure of activity accurately from underlying data } \\
\text { without approximate and indistinct values. }\end{array}$ \\
\hline 2 & Actionable & Employees able to take corrective action to improve performance. \\
\hline 3 & Comprehensive & $\begin{array}{l}\text { It covers all critical processes of airline catering operations (how well the inflight products and } \\
\text { catering service is planned, sourced, made, delivered, and returned). }\end{array}$ \\
\hline 5 & Diagnostic & $\begin{array}{l}\text { Enable the organisation to analyse a performance issue and understand the causes of poor } \\
\text { performance. }\end{array}$ \\
\hline 6 & Informative & $\begin{array}{l}\text { It should provide helpful information such as its origin, owner, time last reviewed and } \\
\text { calculation methodology that a decision-maker can trust and use to quantify the performance } \\
\text { outcome accurately. }\end{array}$ \\
\hline 7 & Practical & $\begin{array}{l}\text { It must be updated regularly to ensure they drive the desired outcome and provide relevant and } \\
\text { timely information. }\end{array}$ \\
\hline 8 & Simple & $\begin{array}{l}\text { Easy to understand and easy to describe to stakeholders regarding what's being measured, how } \\
\text { it is calculated, what is the target. }\end{array}$ \\
\hline 10 & Standardised & $\begin{array}{l}\text { The definitions of terms can be agreed upon by all parties, and that performance measures can } \\
\text { be consistent easily explored/understood at a different level of organisation. }\end{array}$ \\
\hline 4 & $\begin{array}{l}\text { It contains a strategic goal and designed to help the organisation correctly plan, monitor and } \\
\text { adapt airline catering operations and service strategy. }\end{array}$ \\
\hline
\end{tabular}

Table 1. Characteristics of effective performance metrics for adaptation in airline catering supply chain

\subsection{COVID-19 Challenges in Supply Chains}

The COVID-19 has rapidly spread globally since it emerged in 2019. Governments worldwide instituted extensive safety plans such as wearing masks, social distancing, national lockdown and border restrictions to control the pandemic growth and manage health system resilience. These measures result in a negative impact on international trade and cause disruption in the global supply chain. Manufacturing sectors such as the automotive, pharmaceuticals and electronics industries and service sectors like airline and healthcare heavily depend on international supply chain partners. These supply chains have been substantially impacted due to the COVID-19 outbreak (Belhadi, Kamble, Jabbour, Gunasekaran, Ndubisi \& Venkatesh, 2021). Initially, it created direct and immense supply disruptions, then the economic declines in demand along with companies' investment concerns due to uncertainties created demand disruptions. These disruptions in supply and demand would not be uniform across companies and industries. The effect of COVID-19 on the different business sectors will be different due to the dissimilarities in demand and supply patterns (Sharma, Shishodia, Kamble, Gunasekaran \& Belhadi, 2020).

Disease outbreaks such as the COVID-19 pandemic significantly adversely impact businesses and supply chains, including dropping their efficiency and performance (Guan, Wang, Hallegatte, Davis, Huo, Li et al., 2020). Business resilience and sustainability has been affected by the proliferation of COVID-19 disruptions across the supply chains (Ivanov \& Dolgui, 2021). Unlike previous disease outbreaks in the recent past, this pandemic has affected all nodes and links in a supply chain at the same time. As a result, the flow of the products through the supply chain has been severely disrupted. COVID-19 initially hit China, which is at the core of many global value chains and 
disrupts the supply chain (Luo \& Tsang, 2020). The global supply chain has experienced several disruptions in the past; most recently, it has been disrupted by a huge financial crisis during 2008-2009. But, the ongoing COVID-19 pandemic is unique. While the lessons learned from previous events would be useful today, there are some differences in their nature. At that time, it was more of a demand aspect disruption than a supply, whereas the COVID-19 pandemic has had a significant impact on both supply and demand (Goel, Saunoris \& Goel, 2021). On the demand side, global demand continues to decline as the lockdown continues and physical consumer spending reduces. The effects of COVID-19 on supply and demand is already shown in the global oil prices (Fernandes, 2020). The global oil demand has fallen significantly during the pandemic due to the worldwide lockdown and other factors related to COVID-19. Many suppliers and manufacturers have planned to reduce, even stopped some production as demand declined (Goel et al., 2021).

There is an increasing number of studies on the overall risk of the COVID-19 pandemic (Nakamura \& Managi, 2020). For example, Wu, Leung and Leung (2020) analyses the risk of transmission from international flights compared to local flights. Another study predicted the impact of travel limitations on the domestic and global spread of COVID-19 (Chinazzi, Davis, Ajelli, Gioannini, Litvinova, Merler et al., 2020). Nakamura and Managi (2020) measured the importation and exportation risk of the COVID-19 and suggested undertaking strict airport countermeasures. It's absolutely critical to understand the short-term and long-term effects, and conduct adequate risk assessments during black swan incidents like the COVID-19 outbreak. In this way, organisations can determine the appropriate response, mitigation strategies and define performance measures (Kochan \& Nowicki, 2018). So far, the uncertainties and subjectivities associated with the effects of the COVID-19 pandemic in the supply chain have made it difficult to fully define risk scenarios and establish effective response strategies for the long term (Ivanov \& Dolgui, 2020).

A report previously published in Fortune magazine in February 2020, before the COVID-19 outbreak was classified as a pandemic in March 2020, found that 94\% of Fortune 1000 companies experienced disruptions in their supply chains due to COVID-19 infectious disease (Chowdhury, Paul, Kaisar \& Moktadir, 2021). A recent survey about the impact of COVID-19 conducted on 558 manufacturing companies in the U.S. discovered that more than $78 \%$ of companies expected severe economic effects from the uncertainty in their activities caused by the pandemic (Belhadi et al., 2021). Major business enterprises such as automotive companies and retails have been cutting jobs as sales fall due to the ongoing pandemic. The government's lockdown restrictions have forced the closure of several factories and shops as potential buyers locked themselves in the house for a longer period.

Although the extent and cost of this pandemic are not yet known, we know that service sectors heavily dependent on movements, such as airlines and travel, were significantly affected, and recovery would be very slow. The airline industry has faced many troubles throughout history, but no one seems as serious as the one caused by the spread of COVID-19 (Amankwah-Amoah, 2020). The airline workers bear the brunt of COVID-19 volatility, sales declines and uncertainties. The airline industry has seen considerable work losses of almost 7-13\% (Sobieralski, 2020). According to a recent estimate, over 400,000 aviation workers were being furloughed or laid off because of continuing disruption. Many of the world's largest airlines have announced plans to conduct mass job cuts and introduced unpaid leave schemes (Belhadi et al., 2021).

In fact, COVID-related policies of operating social distance measures have an impact on pricing strategy. Many of the major airlines have already introduced some elements of inflight social distancing by not allowing passengers in the middle seats and letting them switch seats if they have any health concerns. Furthermore, some airlines have limited in-flight meals to reduce contact between the cabin crew onboard and the passengers. Other airlines introduced more disposable catering containers and supplies the refreshments and meals for passengers on board by putting the prepacked meal box on the seats. Overall, it is likely low prices are hard to come by, especially for low-cost airlines that compete with the prices through operating high-density seating and selling buy-on-board meals. However, today's airlines have little or no choice but to reduce their flight operations as a result of border restrictions, fear of infection, and long quarantine period. IATA data shows that the occurrence of the pandemic resulted in a sharp drop in airline share prices. This is expected to have a substantial impact on shareholders and the capital value of the global aviation industry (Dube, Nhamo \& Chikodzi, 2021). Experts estimates that restoring the airline sector back to the normal stage would take between four to six years (Sobieralski, 2020). In the face of the 
ongoing crisis, IATA recognises that the airline sector will begin to recover by the end of 2021. Governments need to put plans in place to restart the industry without further delay when the pandemic situation allows the borders to be reopened. IATA has reported that a substantial share of the \$3.5 trillion in GDP and 88 million airlines supported jobs are at risk during the pandemic (IATA, 2021). The actual restart of the airline industry will revitalise the travel and tourism sectors and the economy in general (IATA, 2021). Due to flight cancellation and airport closure, economic losses are likely to force many airlines to look for innovative solutions and new performance measurement systems to survive and thrive.

People are reluctant to travel during the COVID-19 pandemic period due to health and safety concerns arising from the pandemic. Airlines must ensure passengers safety as this would encourage the public to want to travel again. Many different strategies are being adopted by major airlines to assure passengers' comfort, health, and safety. Some of these are wearing a surgical face mask, providing health care kit and hand sanitiser in the gate area before onboarding, personnel protective equipment (PPE) for cabin crew, keeping middle seat empty, temperature check of passengers before onboard, COVID-19 test before travel, using electrostatic spray disinfectant technology, and cabin baggage restrictions (Dube et al., 2021).

Sustainability is a serious issue that requires the airline sector's attention worldwide (Dube \& Nhamo, 2019). Focusing on environmental sustainability becomes harder for some businesses in the short term due to the financial pressures and threats to the company's survival caused by the COVID-19 pandemic. This limits the scope of management and companies to respond to environmental problems. Some environmentalists and activists have suggested that many industries, including airlines, use the pandemic to give up or to further delay in putting organisational measures to the climate change programme (Amankwah-Amoah, 2020). In this COVID-19 situation, airlines can no longer rely alone on environmental pledges for the market competition but also need to ensure additional health and safety measures in protecting their passengers' health by avoiding possible viral infections in their in-flight service facilities. Therefore, setting a healthy environment has emerged as a key factor of competitive advantage for airlines. To lower COVID-19 effects and attract lasting success, airline managers and executives need to be innovative in ways to offer healthy assurance of service to passengers.

In addition, the COVID-19 pandemic disruption in the airline sector has had a significant impact on several other dependent industries, such as aircraft manufacturing, hotel, tourism and airline catering businesses (Martin, Markhvida, Hallegatte \& Walsh, 2020). It is important to study the airline catering industry's performance measures considerations and strategies during the COVID-19 pandemic, especially regarding managing airline catering supply chains in a crisis.

\section{Supply Chain Operations Reference Framework}

The Supply Chain Operations Reference model (SCOR) is a unique framework that provides the methodology and diagnostic tools for organisations to understand their supply chain processes (APICS, 2017). This model connects people, processes, best practices and performance metrics within a structured framework (Kusrini, Caneca, Helia \& Miranda, 2019). The framework helps supply chain professionals identify the critical features for customer satisfaction and improve supply chain management effectiveness.

This reference model was developed and endorsed by Supply Chain Council (SCC). It has evolved based on extensive feedback from industry leaders who manage supply chains and apply the reference model regularly to improve business performance. SCC merged into the American Production and Inventory Control Society (APICS) and became known as APICS SCC. The APICS SCC has released its most recent version of the framework, SCOR 12.0.

The SCOR model is organised around six primary management processes (plan, source, make, deliver, return and enable). It helps organisations evaluate their supply chain's design to make improvements and identify any redundant and inefficient practices along their supply chain to eliminate them. Though it covers all customer interactions, physical materials interactions and market interactions, it does not intend to define every business process or activity. As a business framework, it explains how these major processes interact, the link between supplier's supplier to customer's customer is configured, and the understanding of the demand for order fulfilment. 
SCOR model is a flexible and customisable framework that can be adapted as per the business requirements and applied to different industries and conditions. The SCOR model helps define the organisation's processes for all stages of supply chain activities. It also classifies supply chain performance metrics to measure whether processes are being effectively managed and business goals are being met.

\section{Methodology}

A case study approach is adopted in this paper. An airline catering service provider based in the United Kingdom referred to in this paper as Company-X participated in this case study. Airline catering logistics processes of Company-X was first directly observed, and AS-IS business analysis of the company was conducted to understand the business processes of airline catering operations at a high level. In addition, operational practices of Company-X was observed including shop-floor operations in order to capture current supply chain processes in the warehouse, and the food assembly operations, at the company's airline catering service centre. Following an understanding of airline catering operations, a focus group that consists of ten senior supply chain management professionals in the case study organisation was formed. The participants were chosen for their expertise in the functional areas and in measuring the performance of airline catering supply chains. They were heads of departments and senior operations and supply chain managers. Each of the participants in this study had at least a minimum of ten years of relevant experience in the airline catering business, and the average overall experience was 11.5 years.

The case study research is in three stages. First, the airline catering SCOR model was developed for company X, focusing on the Level 1 strategic metrics and Level 2, 3 diagnostic metrics in the SCOR framework. The airline catering SCOR model developed is validated by the focus group participants. Second, diagnostic performance metrics, i.e., Level 2, 3 SCOR metrics, were prioritised by the focus group. Finally, in the third stage, the focus group participants identified changes in their considerations of the performance measures as the result of COVID-19 pandemic. The focus group participants also discussed the effects of the COVID-19 pandemic on the choices of their performance metrics.

The study was conducted mainly through semi-structured interviews and questionnaires. Semi-structured interviews were used in the first stage of the study. Two questionnaires were used to collect the data in the second and third stages of the study. The prioritisation method used in Stage 2 of the study is the MoSCoW prioritisation method. MoSCoW is used in this study to answer the question: Which metrics are most vital to the effectiveness of the airline catering supply chain and which are less important during the COVID-19 pandemic?. The MoSCoW prioritisation technique was applied in the first questionnaire administered to the focus group participants, to capture their perspectives on performance measure priorities. The MoSCoW method is one of the oldest and promising prioritisation techniques commonly used in the software engineering discipline (Tufail, Qasim, Masood, Tanvir \& Butt, 2019). It's very useful for the hierarchical classification of user requirements and prioritising them relatively fast (Beltman, Vosslamber, Molderink \& Noordzij, 2016). It's very important to get the MoSCoW definitions unambiguously with the stakeholders to avoid the results based on personal opinions and better align with the business goals. The letters $(\mathrm{Mo}, \mathrm{S}, \mathrm{Co}, \mathrm{W})$ of this prioritisation technique in this scenario are given in Table 2 below. The second questionnaire is used in the third stage of this study to collect data on performance considerations regarding the adaptation of performance attributes and supply chain processes during COVID-19.

Must have (Mo)

Should have

(S)

Could have

(Co)

Won't have

(W)
Non-negotiable metrics that are mandatory for airline catering supply chain/logistics performance measurement during the COVID-19 pandemic.

Important metrics that are not vital, but add significant value for airline catering supply chain/logistics performance measurement during the COVID-19 pandemic.

Nice to have metrics that will have a small impact on airline catering supply chain/logistics performance if not measured during the COVID-19 pandemic.

Performance metrics that are not a priority for airline catering supply chain/logistics performance during the COVID-19 pandemic. 
The two questionnaires were given out to the ten senior managers in the focus group. In the first questionnaire, 48 MoSCoW questions with respect to the previously defined Levels 2 and 3 performance metrics were formed. These MoSCoW questions were placed under the six process perspectives-Plan, Source, Make, Deliver, Return, and Enable. The respondents were asked to choose the category from MoSCoW classification to determine the priority for each metric. After the questionnaires were received from the respondents, the performance metrics were aggregated. The mean values of the metrics were derived and assigned to the relevant priority group.

\section{Airline Catering SCOR Model}

Airline catering logistics is the process of planning, implementing, and controlling the flow and storage of a vast amount of airline meals, beverages and catering equipment for all cabin classes along with crew meals from the kitchen to aircraft to meet the airline catering requirements. While airline catering logistics shares similarities with other commercial logistics services in the processes such as streamlining the supply chain activities, transporting goods and implementing a cost-effective operation, the airline catering business differs on its supply chain structure, stakeholders, the operational environment, complexity, demand, and requirements. These unique characteristics make performance measurement in airline catering logistics challenging. Logistics service providers in the airline catering supply chain manage a significant part of the entire supply chain and offer a complete airline catering solution. They deliver a range of solutions covering; planning and design, sourcing and supply management, assembly operations, airport operations, final mile delivery and returns management. They provide one-stop-shop catering services to the airline customer.

Though the SCOR model has been applied widely in various industries to improve supply chain efficiency (Lemghari, Okar \& Sarsri, 2018), the application of this performance measurement model to the airline catering industry is limited. This paper provides airline catering organisations, professionals, and supply chain researchers with baseline information on applying the SCOR model in the airline catering supply chain, with a focus on airline catering service requirements. Hence, the airline catering SCOR model attempts to recognise the association between the supply chain functions and the airline catering logistics challenges across all stages of the catering order fulfilment cycle. The airline catering operation defined in this research is based on the six primary management processes organised in the SCOR model: plan, source, make, deliver, return and enable.

These six core processes cover all phases in an airline catering supply chain, starting from catering orders sent by airlines to transactions of airline catering materials such as catering equipment, containers, meals and beverages; and interactions with airlines, suppliers and caterers in order to plan for catering demand and fulfil airline orders to the aircraft. By classifying the airline catering supply chain in these six primary processes, the airline catering SCOR model establishes a set of indicators that can assist the measurement of airline catering supply chain performance.

While conducting the case study, the need to adapt SCOR model to be appliable to the airline catering environment was realised. The current SCOR model was generic and did not directly cover all functions in the airline catering supply chain. The adapted version of the airline catering SCOR model is shown in Figure 2 and covers all supply chain activities involved in the airline catering environment under six management processes, namely, plan, source, make, deliver, return and enable. This model defines unique processes an airline catering supply chain requires to operate in order to achieve its primary goal of fulfilling airline catering orders.

Plan: The planning process of the airline catering SCOR model describes all the activities related to developing the plan for operating the airline catering supply chain. This process deals with collecting airline catering requirements, gathering available resource related information, matching the demands with the resources to understand the gaps and operational capabilities.

Source: The source management process includes all the activities involved in sourcing meals, beverages, ancillaries and packaging items from the suppliers and ordering or scheduling and the receipt of any other rotable, consumable or disposable products owned by airlines such as catering containers, equipment and bar items. This process includes determining catering order requirements, creating purchase orders or scheduling deliveries, receiving goods by checking the type of products and quantities against the purchase order, storing the goods in appropriate storage areas, verifying and accepting the invoice from the supplier. 


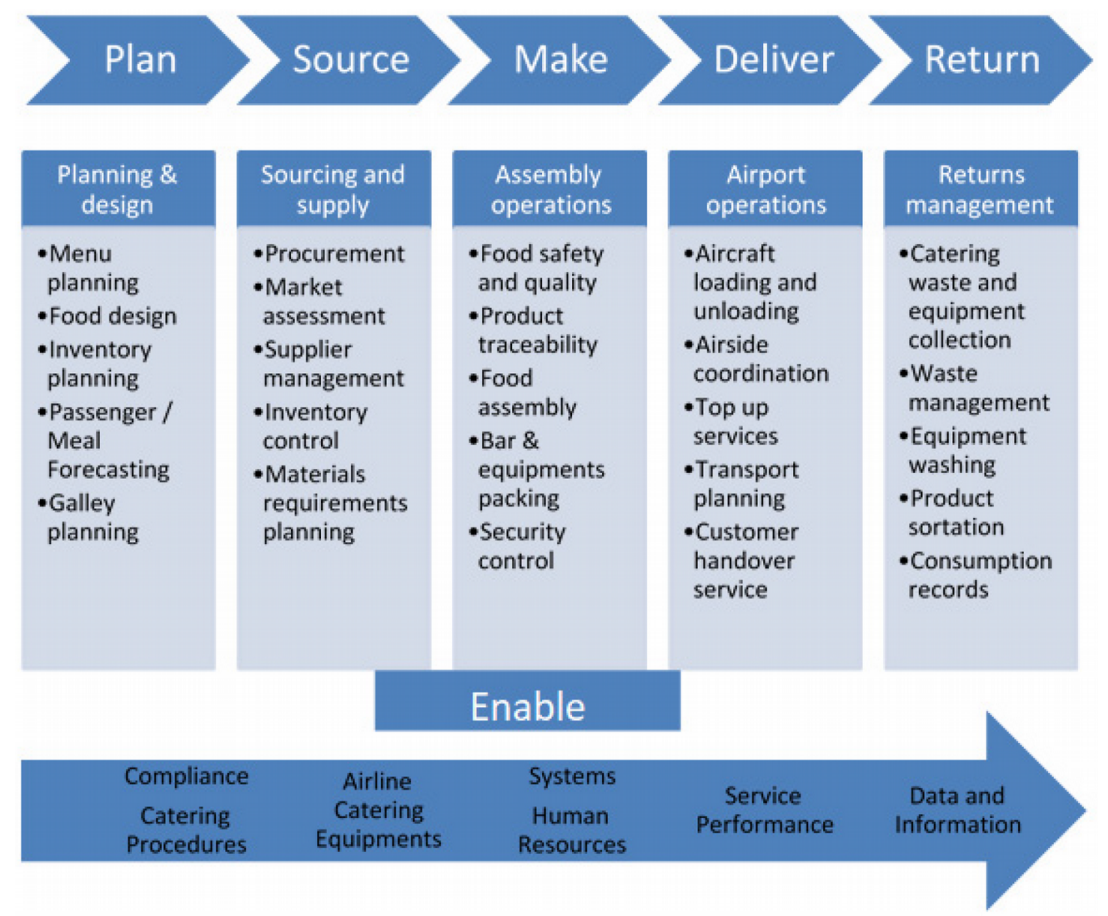

Figure 2. SCOR model of airline catering supply chain

Make: Make is the management process that describes the conversion activity of materials or creation of meal, bar and equipment content for airline catering service. The research reported in this paper focuses on assembly operations rather than manufacturing or production function as there are no cooking activities on-site in company $\mathrm{X}$ but outsourced to the food manufacturers and/or suppliers. ATO (Assemble to Order) production in this airline catering organisation means the components of the final catering products are assembled after the airline order is received according to the catering requirements and appropriate specifications.

Deliver: The deliver process consists of all activities associated with creating, managing, and fulfilling airline catering orders. This process includes the receipt of all relevant information from airlines to process the catering order request, validating the information such as flight details, meal-type and quantities and creating the sales orders with reference to the catering request. Transportation of catering containers to the aircraft is one of the core activities in the airline catering logistics service. Airline catering organisation need to ensure that the food is delivered to the right flight at the right time in appropriate condition.

Return: The return process defines all the activities involved in managing the reverse flow of catering equipment and waste from aircraft. On arrival, all the catering containers, equipment and catering waste will be collected from the return flights and transported back to the assembly centre. The airline catering organisation collects, stores, and disposes the catering waste as part of their reverse logistics process and supports the airline to meet its sustainability objectives.

Enable: Enable process is the core of the SCOR model that defines all the business functions associated with managing the airline catering supply chain. These functions include business continuity management, dealing with aviation regulatory compliance, managing airline catering procedures, performance management, continuous improvement initiatives, and implementing sustainability strategies.

\subsection{Adoption of SCOR Performance Measures for Airline Catering Supply Chain}

The SCOR model provides a comprehensive approach to understanding and diagnosing supply chain performance by measuring and assessing the supply chain execution processes (Delipinar \& Kocaoglu, 2016). The performance section of SCOR framework consists of three elements. They are performance attributes, metrics and process maturity. A performance attribute is a classification of metrics that are used to define a specific strategy. SCOR model defines five performance attributes (Reliability, Responsiveness, Agility, Cost and Asset Management 
Efficiency) to measure and assess the outcome of supply chain execution. They can be applied in different industries to address specific supply chain performance concerns. The SCOR model's strategic characteristics help organisations align the supply chain performance with their business strategy (Girjatovičs, Rizoto-Vidala-Pesoa \& Kuzņecova, 2018).

\begin{tabular}{|c|c|c|c|}
\hline & $\begin{array}{l}\text { Performance } \\
\text { Attribute }\end{array}$ & SCOR Attribute Definition & $\begin{array}{l}\text { Associated Definition for Airline Catering } \\
\text { Supply Chain }\end{array}$ \\
\hline \multirow{3}{*}{$\begin{array}{l}\text { Customer } \\
\text { facing } \\
\text { attributes }\end{array}$} & Reliability & $\begin{array}{l}\text { The ability to perform tasks as expected. } \\
\text { Reliability focuses on the predictability } \\
\text { of the outcome of a process. }\end{array}$ & $\begin{array}{l}\text { Consistently fulfilling the airline orders right, } \\
\text { service meets the catering requirements. The } \\
\text { ability to cater the correct meal offering with the } \\
\text { right quantity in the appropriate condition } \\
\text { according to the catering specification and load } \\
\text { onto the aircraft on time as per the flights' } \\
\text { departure schedules. }\end{array}$ \\
\hline & Responsiveness & $\begin{array}{l}\text { The speed at which tasks are performed. } \\
\text { The speed at which a supply chain } \\
\text { provides products to the customer. }\end{array}$ & $\begin{array}{l}\text { The consistent speed of providing the catering } \\
\text { service to Airlines. }\end{array}$ \\
\hline & Agility & $\begin{array}{l}\text { The agility of a supply chain in } \\
\text { responding to external influences and } \\
\text { marketplace changes to gain or maintain } \\
\text { competitive advantage. }\end{array}$ & $\begin{array}{l}\text { The ability to respond to catering service } \\
\text { requirements changes in the airline business } \\
\text { environment. }\end{array}$ \\
\hline \multirow{2}{*}{$\begin{array}{l}\text { Internal } \\
\text { facing } \\
\text { attributes }\end{array}$} & Cost & $\begin{array}{l}\text { The cost related to operating the supply } \\
\text { chain processes. This includes labour } \\
\text { costs, material costs, and management } \\
\text { and transportation costs. }\end{array}$ & $\begin{array}{l}\text { The cost associated with managing and operating } \\
\text { the airline catering supply chain. The cost of } \\
\text { catering, decatering flights and aviation security } \\
\text { compliance, as well as the catering equipment } \\
\text { washup cost. }\end{array}$ \\
\hline & Assets & $\begin{array}{l}\text { The effectiveness of a supply chain in } \\
\text { utilising assets to support demand } \\
\text { satisfaction. It includes inventory } \\
\text { reduction. }\end{array}$ & $\begin{array}{l}\text { The ability to efficiently manage the airline } \\
\text { catering equipment, inventory of meals and } \\
\text { beverages in support of airline order fulfilment. }\end{array}$ \\
\hline
\end{tabular}

Table 3. Linking SCOR performance attributes with airline catering logistics performance

Table 3 above shows the performance attributes definition of the SCOR model and associates the attributes with the corresponding airline catering service definition that are used as the guide for creating measurable airline catering supply chain performance metrics.

\section{Performance Metrics Development}

A performance metric is a standard for measuring the effectiveness of supply chain processes. Many organisations lack a clear vision to implement effective metrics for their supply chain performance (Kottala \& Herbert, 2019). In this research, measurable logistics service metrics applicable to the airline catering supply chain have been developed for each airline catering SCOR service performance attribute, as shown in Table 4.

\begin{tabular}{|l|l|l|l|}
\hline Metric No & \multicolumn{1}{|c|}{ Metric } & $\begin{array}{c}\text { Performance attribute } \\
\text { and process }\end{array}$ & \multicolumn{1}{c|}{ Definition } \\
\hline AC_RL.1.1 & $\begin{array}{l}\text { Perfect Order } \\
\text { Fulfillment }\end{array}$ & $\begin{array}{l}\text { Reliability and All } \\
\text { Processes }\end{array}$ & $\begin{array}{l}\text { The percentage of orders meeting delivery performance } \\
\text { with complete and accurate documentation. }\end{array}$ \\
\hline AC_RL.2.1 & $\begin{array}{l}\text { \% of Orders } \\
\text { Delivered in Full }\end{array}$ & Reliability and Deliver & $\begin{array}{l}\text { Percentage of orders which all of the items are received } \\
\text { by customer in the quantities committed. }\end{array}$ \\
\hline AC_RL.2.2 & $\begin{array}{l}\text { Delivery } \\
\text { Performance to } \\
\text { Customer Commit } \\
\text { Date }\end{array}$ & Reliability and Deliver & $\begin{array}{l}\text { The percentage of orders that are fulfilled on the } \\
\text { customer's originally committed date. }\end{array}$ \\
\hline
\end{tabular}




\begin{tabular}{|c|c|c|c|}
\hline Metric No & Metric & $\begin{array}{l}\text { Performance attribute } \\
\text { and process }\end{array}$ & Definition \\
\hline AC_RL.2.3 & $\begin{array}{l}\text { Documentation } \\
\text { Accuracy }\end{array}$ & Reliability and Deliver & $\begin{array}{l}\text { Percentage of orders with on time and accurate } \\
\text { documentation. }\end{array}$ \\
\hline AC_RL.2.4 & Perfect Condition & Reliability and Deliver & $\begin{array}{l}\text { Percentage of orders delivered in an undamaged state } \\
\text { that meet specification. }\end{array}$ \\
\hline AC_RL.3.1 & $\begin{array}{l}\text { Delivery Item } \\
\text { Accuracy }\end{array}$ & Reliability and Deliver & $\begin{array}{l}\text { Percentage of orders in which all items ordered are the } \\
\text { items actually provided, and no extra items are provided. }\end{array}$ \\
\hline AC_RL.3.2 & $\begin{array}{l}\text { Delivery Quantity } \\
\text { Accuracy }\end{array}$ & Reliability and Deliver & $\begin{array}{l}\text { Percentage of orders in which all quantities received by } \\
\text { the customer match the order quantities. }\end{array}$ \\
\hline AC_RL.3.3 & $\begin{array}{l}\text { Customer Commit } \\
\text { Date, Time } \\
\text { Achievement }\end{array}$ & Reliability and Deliver & $\begin{array}{l}\text { Percentage of orders which is received on time as defined } \\
\text { by the customer. }\end{array}$ \\
\hline AC_RL.3.4 & $\begin{array}{l}\text { Delivery Location } \\
\text { Accuracy }\end{array}$ & Reliability and Deliver & $\begin{array}{l}\text { Percentage of orders which is delivered to the correct } \\
\text { location and customer entity. }\end{array}$ \\
\hline AC_RL.3.5 & $\begin{array}{l}\text { Compliance } \\
\text { Documentation } \\
\text { Accuracy }\end{array}$ & Reliability and Make & $\begin{array}{l}\text { Percentage of compliance documentations are complete, } \\
\text { correct, and readily available. }\end{array}$ \\
\hline AC_RL.3.6 & $\begin{array}{l}\% \text { Orders } / \text { lines } \\
\text { received damage free }\end{array}$ & Reliability and Source & $\begin{array}{l}\text { The number of orders / lines that are processed damage } \\
\text { free divided by the total orders / lines processed in the } \\
\text { measurement period. }\end{array}$ \\
\hline AC_RL.3.7 & $\begin{array}{l}\text { \% Item Location } \\
\text { Accuracy }\end{array}$ & Reliability and Deliver & Percentage of item location accuracy. \\
\hline AC_RL.3.8 & $\begin{array}{l}\% \text { Orders/ Lines } \\
\text { Received On-Time } \\
\text { to Demand } \\
\text { Requirement }\end{array}$ & Reliability and Source & $\begin{array}{l}\text { Number of orders / lines that are received on- time to } \\
\text { the demand requirements divided by the total orders / } \\
\text { lines for the demand requirements in the measurement } \\
\text { period. }\end{array}$ \\
\hline AC_RL.3.9 & $\begin{array}{l}\% \text { Orders / lines } \\
\text { received with correct } \\
\text { content }\end{array}$ & Reliability and Source & $\begin{array}{l}\text { Percentage of orders or lines received that have the } \\
\text { correct material content as specified in the product } \\
\text { design specs and supplier agreements. }\end{array}$ \\
\hline AC_RL.3.10 & Forecast Accuracy & Reliability and Plan & $\begin{array}{l}\text { Common calculation (Sum Actuals - Sum of Variance) / } \\
\text { Sum Actuals to determine percentage error. }\end{array}$ \\
\hline AC_RL.3.11 & $\begin{array}{l}\text { Schedule } \\
\text { Achievement }\end{array}$ & Reliability and Make & $\begin{array}{l}\text { The percentage of time that a plant achieves its } \\
\text { production schedule. }\end{array}$ \\
\hline AC_RL.3.12 & Yield & Reliability and Make & The ratio of usable output from a process to its input. \\
\hline AC_RS.1.1 & $\begin{array}{l}\text { Order Fulfillment } \\
\text { Cycle Time }\end{array}$ & $\begin{array}{l}\text { Responsiveness and All } \\
\text { Processes }\end{array}$ & $\begin{array}{l}\text { The average actual cycle time consistently achieved to } \\
\text { fulfill customer orders. }\end{array}$ \\
\hline AC_RS.2.1 & Source Cycle Time & $\begin{array}{l}\text { Responsiveness and } \\
\text { Source }\end{array}$ & The average time associated with Source Processes. \\
\hline AC_RS.2.2 & Make Cycle Time & Responsiveness and Make & The average time associated with Make Processes. \\
\hline AC_RS.2.3 & Deliver Cycle Time & $\begin{array}{l}\text { Responsiveness and } \\
\text { Deliver }\end{array}$ & The average time associated with Deliver Processes. \\
\hline AC_RS.2.4 & Return Cycle Time & $\begin{array}{l}\text { Responsiveness and } \\
\text { Return }\end{array}$ & The average time associated with Return Processes. \\
\hline AC_RS.3.1 & $\begin{array}{l}\text { Current logistics } \\
\text { order cycle time }\end{array}$ & $\begin{array}{l}\text { Responsiveness and } \\
\text { Deliver }\end{array}$ & $\begin{array}{l}\text { Current logistics order cycle time, including customer } \\
\text { order processing cycle time, dock-to- stock cycle time, } \\
\text { pick-to-ship cycle, transit time, etc. }\end{array}$ \\
\hline AC_RS.3.2 & $\begin{array}{l}\text { Establish Delivery } \\
\text { Plans Cycle Time }\end{array}$ & Responsiveness and Plan & $\begin{array}{l}\text { The average time associated with establishing and } \\
\text { communicating deliver plans. }\end{array}$ \\
\hline AC_RS.3.3 & $\begin{array}{l}\text { Establish Production } \\
\text { Plans Cycle Time }\end{array}$ & Responsiveness and Plan & $\begin{array}{l}\text { The average time associated with establishing and } \\
\text { communicating production plans. }\end{array}$ \\
\hline AC_RS.3.4 & $\begin{array}{l}\text { Establish Sourcing } \\
\text { Plans Cycle Time }\end{array}$ & Responsiveness and Plan & $\begin{array}{l}\text { The average time associated with establishing and } \\
\text { communicating source plans. }\end{array}$ \\
\hline
\end{tabular}




\begin{tabular}{|c|c|c|c|}
\hline Metric No & Metric & $\begin{array}{l}\text { Performance attribute } \\
\text { and process }\end{array}$ & Definition \\
\hline AC_RS.3.5 & $\begin{array}{l}\text { External Event } \\
\text { Response (average } \\
\text { days) }\end{array}$ & $\begin{array}{l}\text { Responsiveness and } \\
\text { Enable }\end{array}$ & $\begin{array}{l}\text { The average response time (in days) to an external risk } \\
\text { event from the time of the event. }\end{array}$ \\
\hline AC_RS.3.6 & In-stock \% & $\begin{array}{l}\text { Responsiveness and } \\
\text { Deliver }\end{array}$ & $\begin{array}{l}\text { Percentage of materials, components, or finished goods } \\
\text { that are there when needed. }\end{array}$ \\
\hline AC_RS.3.7 & $\begin{array}{l}\text { Receive Excess } \\
\text { Product Cycle Time }\end{array}$ & $\begin{array}{l}\text { Responsiveness and } \\
\text { Return }\end{array}$ & $\begin{array}{l}\text { The average time associated with receiving excess } \\
\text { product returns from the customer. }\end{array}$ \\
\hline AC_AG.1.1 & $\begin{array}{l}\text { Upside Supply Chain } \\
\text { Adaptability }\end{array}$ & Agility and All Processes & $\begin{array}{l}\text { The maximum sustainable percentage increase in quantity } \\
\text { delivered that can be achieved in } 30 \text { days. }\end{array}$ \\
\hline AC_AG.1.2 & $\begin{array}{l}\text { Downside Supply } \\
\text { Chain Adaptability }\end{array}$ & Agility and All Processes & $\begin{array}{l}\text { The reduction in quantities ordered sustainable at } 30 \text { days } \\
\text { prior to delivery with no inventory or cost penalties. }\end{array}$ \\
\hline AC_AG.2.1 & $\begin{array}{l}\text { Upside Adaptability } \\
\text { (Source) }\end{array}$ & Agility and Source & $\begin{array}{l}\text { Maximum sustainable percentage increase in raw material } \\
\text { quantities that can be acquired/ received in } 30 \text { days. }\end{array}$ \\
\hline AC_AG.2.2 & $\begin{array}{l}\text { Upside Adaptability } \\
\text { (Make) }\end{array}$ & Agility and Make & $\begin{array}{l}\text { The maximum sustainable percentage increase in } \\
\text { production that can be achieved in } 30 \text { days. }\end{array}$ \\
\hline AC_AG.2.3 & $\begin{array}{l}\text { Upside Adaptability } \\
\text { (Deliver) }\end{array}$ & Agility and Deliver & $\begin{array}{l}\text { The maximum sustainable percentage increase in } \\
\text { quantities delivered that can be achieved in } 30 \text { days. }\end{array}$ \\
\hline AC_AG.2.4 & $\begin{array}{l}\text { Downside } \\
\text { Adaptability (Source) }\end{array}$ & Agility and Source & $\begin{array}{l}\text { The raw material quantity reduction sustainable at } 30 \text { days } \\
\text { prior to delivery with no inventory or cost penalties. }\end{array}$ \\
\hline AC_AG.2.5 & $\begin{array}{l}\text { Downside } \\
\text { Adaptability (Make) }\end{array}$ & Agility and Make & $\begin{array}{l}\text { The production reduction sustainable at } 30 \text { days prior to } \\
\text { delivery with no inventory or cost penalties. }\end{array}$ \\
\hline AC_AG.2.6 & $\begin{array}{l}\text { Downside } \\
\text { Adaptability } \\
\text { (Deliver) }\end{array}$ & Agility and Deliver & $\begin{array}{l}\text { The reduction in delivered quantities sustainable at } 30 \\
\text { days prior to delivery with no inventory or cost penalties. }\end{array}$ \\
\hline AC_AG.3.1 & $\begin{array}{l}\% \text { of labor used in } \\
\text { logistics, not used in } \\
\text { direct activity }\end{array}$ & Agility and Deliver & $\begin{array}{l}\text { Percent of labor used in logistics, not used in direct } \\
\text { activity. }\end{array}$ \\
\hline AC_AG.3.2 & $\begin{array}{l}\% \text { of labor used in } \\
\text { production, not used } \\
\text { in direct activity }\end{array}$ & Agility and Make & $\begin{array}{l}\text { Percentage of labor used in production, not used in } \\
\text { direct activity. }\end{array}$ \\
\hline AC_CO.1.1 & $\begin{array}{l}\text { Total SC } \\
\text { Management Cost }\end{array}$ & Cost and All Processes & $\begin{array}{l}\text { The sum of the costs associated with the processes to } \\
\text { Plan, Source, Make, Deliver, and Return. }\end{array}$ \\
\hline AC_CO.1.2 & Cost of Goods Sold & Cost and All Processes & $\begin{array}{l}\text { The cost associated with buying raw materials and } \\
\text { producing finished goods. }\end{array}$ \\
\hline AC_CO.2.1 & Cost to Plan & Cost and Plan & The sum of the costs associated with Plan. \\
\hline AC_CO.2.2 & Cost to Source & Cost and Source & The sum of the costs associated with Source. \\
\hline AC_CO.2.3 & Cost to Make & Cost and Make & The sum of the costs associated with Make. \\
\hline AC_CO.2.4 & Cost to Deliver & Cost and Deliver & The sum of the costs associated with Deliver. \\
\hline AC_CO.2.5 & Mitigation Cost & Cost and Enable & $\begin{array}{l}\text { The sum of the costs associated with managing non- } \\
\text { systemic risks that arise from special cause variations } \\
\text { within the supply chain. }\end{array}$ \\
\hline AC_CO.3.1 & Direct Material Cost & Cost and Enable & Direct cost spent on material for production. \\
\hline AC_CO.3.2 & $\begin{array}{l}\text { Indirect Cost } \\
\text { Related to } \\
\text { Production }\end{array}$ & Cost and Enable & Indirect cost spent incurred in production indirectly. \\
\hline AC_CO.3.3 & Direct Labor Cost & Cost and Enable & Direct cost spent on production labor. \\
\hline AC_AM.1.1 & $\begin{array}{l}\text { Cash to Cash Cycle } \\
\text { Time }\end{array}$ & $\begin{array}{l}\text { Asset Management and } \\
\text { All Processes }\end{array}$ & $\begin{array}{l}\text { The time it takes for an investment made to flow back } \\
\text { into a company after it has been spent for raw materials. }\end{array}$ \\
\hline AC_AM.2.1 & $\begin{array}{l}\text { Inventory Days of } \\
\text { Supply }\end{array}$ & $\begin{array}{l}\text { Asset Management and } \\
\text { Plan }\end{array}$ & $\begin{array}{l}\text { The amount of inventory (stock) expressed in days of } \\
\text { sales. }\end{array}$ \\
\hline
\end{tabular}




\begin{tabular}{|l|l|l|l|}
\hline Metric No & \multicolumn{1}{|c|}{ Metric } & $\begin{array}{c}\text { Performance attribute } \\
\text { and process }\end{array}$ & \multicolumn{1}{c|}{ Definition } \\
\hline AC_AM.3.1 & $\begin{array}{l}\text { Percentage Excess } \\
\text { Inventory }\end{array}$ & $\begin{array}{l}\text { Asset Management and } \\
\text { Return }\end{array}$ & $\begin{array}{l}\text { The value of excess inventory as a percentage of the } \\
\text { value of total inventory. }\end{array}$ \\
\hline AC_AM.3.2 & Capacity Utilisation & $\begin{array}{l}\text { Asset Management and } \\
\text { Enable }\end{array}$ & $\begin{array}{l}\text { A measure of how intensively a resource is being used to } \\
\text { produce a good or service. }\end{array}$ \\
\hline AC_AM.3.3 & $\begin{array}{l}\text { Rebuild or recycle } \\
\text { rate }\end{array}$ & $\begin{array}{l}\text { Asset Management and } \\
\text { Return }\end{array}$ & $\begin{array}{l}\text { Number of returned products that are rebuilt or recycled } \\
\text { as a percent of the total number of products returned. }\end{array}$ \\
\hline AC_AM.3.4 & Return Rate & $\begin{array}{l}\text { Asset Management and } \\
\text { Return }\end{array}$ & $\begin{array}{l}\text { Quantity of products returned divided by the quantity of } \\
\text { products shipped. }\end{array}$ \\
\hline
\end{tabular}

Table 4. Proposed SCOR metrics for the airline catering supply chain. Adapted from SCOR Model Version 12.0 (APICS, 2017)

The metrics developed for the airline catering supply chain are categorised into their relevant performance attribute class and demonstrates a specific strategy. Each performance attribute in the model defines a strategic direction by grouping a relevant set of metrics. These metrics measure the capabilities to achieve the strategic objectives of logistics service provision in airline catering.

Reliability is the customer focusing performance attribute, and it is an essential requirement for airline catering operations. The key performance indicator i.e. strategic (Level 1) metric for the reliability attribute, in the airline catering SCOR framework developed, is Perfect Order Fulfilment. Responsiveness is also a customer focusing performance attribute in the airline catering supply chain and another essential requirement with the 'Airline Order Fulfilment Cycle Time' metric defined as its strategic metric. Agility is also a customer focus performance attribute. The key performance indicator for Agility in airline catering SCOR is 'Adaptability', and it measures the ability to react to external factors. It includes any non-forecastable increase or decrease in catering demand that requires the ability to change the service level with speed and accuracy. It is critical in airline catering operations as airline catering organisations face volatile passenger demand and need to adjust their catering service rapidly according to the ever-changing and time-sensitive airline environment.

The internal-facing performance attributes in the model are cost and asset. Cost is a crucial element in airline catering operations as airlines are facing high-cost pressure, tightening the profit margin for airline catering companies. The airline catering SCOR key performance indicators for cost include the 'Total Airline Catering Supply Chain Management Cost' and the 'Cost of Meals Sold'. Asset attribute measures how efficiently the airline catering organisation utilise the assets efficiently. Inventory reduction of airline catering equipment and catering products are the key asset management strategies in the airline catering supply chain.

\section{Results and Discussion \\ 6.1. Case Study Results}

Figure 3 shows the priority groups for the fifty-five performance metrics presented in Table 4, based on the perspectives of the focus group participants. It excludes the strategic metrics as company X recognised all Level 1 metrics are essential. The priority groups correspond to the four MoSCoW quadrants of Must-have (Mo), Should-have (S), Could-have (Co), and Won't-have (W). The first group, the Must-have quadrant, in Figure 3, consists of metrics that are most vital for performance measures during COVID-19. It includes four metrics on Reliability, four metrics on Responsiveness, two on Agility, two metrics on Cost, and one on Asset Management Efficiency. The focus group participants also recognised another set of 15 metrics in the next group, the Should-have quadrant, in Figure 3, to add significant value for airline catering supply chain and logistics performance measurement during the COVID-19 disruptive period. The third group, the Could-have quadrant, in Figure 3, consists of 15 metrics considered desirable KPIs but have a smaller business impact when they are not implemented. Finally, the last group, the Won't-have quadrant, in Figure 3, consists of five metrics that are perceived not to be a priority for the airline catering supply chain and logistics performance during the COVID-19 pandemic. 


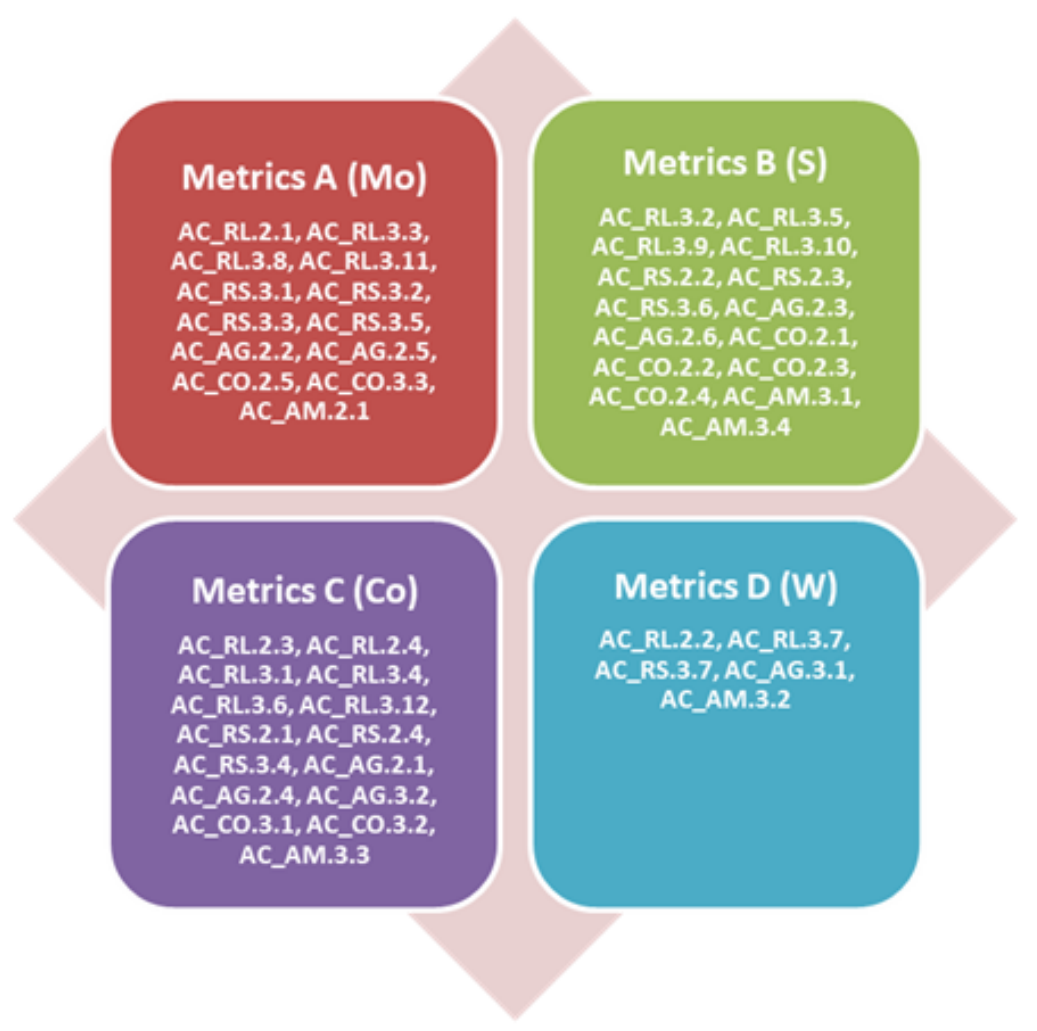

Figure 3. Priority Groups for the Performance Metrics

Figure 4 below shows how performance measurement considerations regarding performance attributes have changed for the case study airline catering organisation during the COVID-19 pandemic.

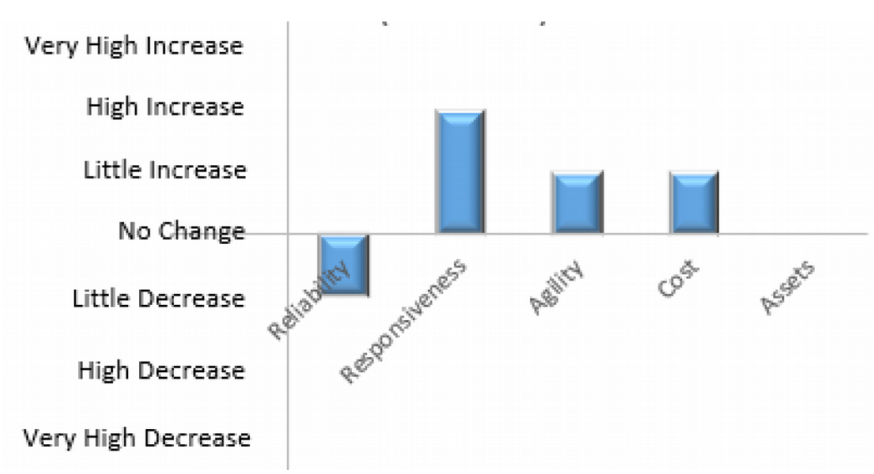

Figure 4. Performance measurement considerations by attribute during COVID-19 pandemic

Performance consideration regarding the responsiveness attribute had a high increase in emphasis. The attributes agility, cost related performance considerations have also increased a little. On the other hand, reliability related performance consideration shows a slight decrease, and no change was recognised in the assets management efficiency attribute.

Figure 5 below shows how much the process-related performance considerations have changed during the COVID-19 disruption, as perceived by the focus group participants. According to Figure 5, the airline catering organisation appears to give considerations towards placing more emphasis on plan and enable processes during the pandemic. Performance considerations for the make and deliver processes have decreased a little in emphasis, whilst the source and return processes have highly decreased in emphasis. 


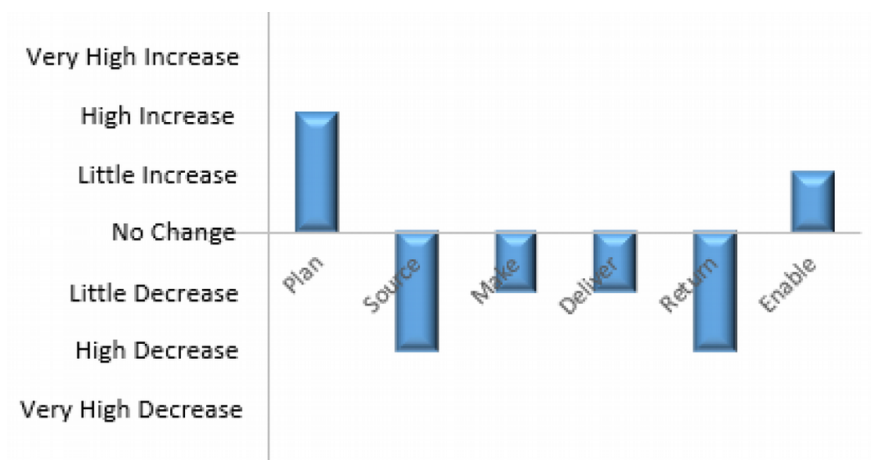

Figure 5. Performance measurement considerations by process during COVID-19 pandemic

Figure 6 below illustrates the perception of the focus group participants on the relative weights of performance attributes in each of the MoSCoW priority groups. The weight of a performance attribute in a priority group is derived from the number of corresponding performance metrics of the attributes within the priority group.

Figure 7 below shows the perception of the focus group participants on the relative weights of supply chain processes in each of the MoSCoW priority groups. The weight of a process in a priority group is derived from the number of corresponding performance metrics of the processes within the priority group.

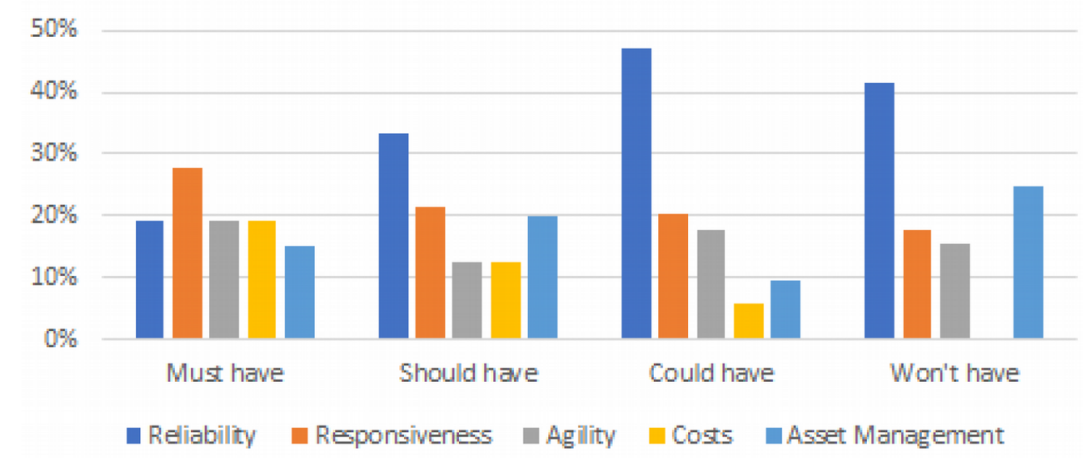

Figure 6. Analysis of prioritised metrics by performance attribute

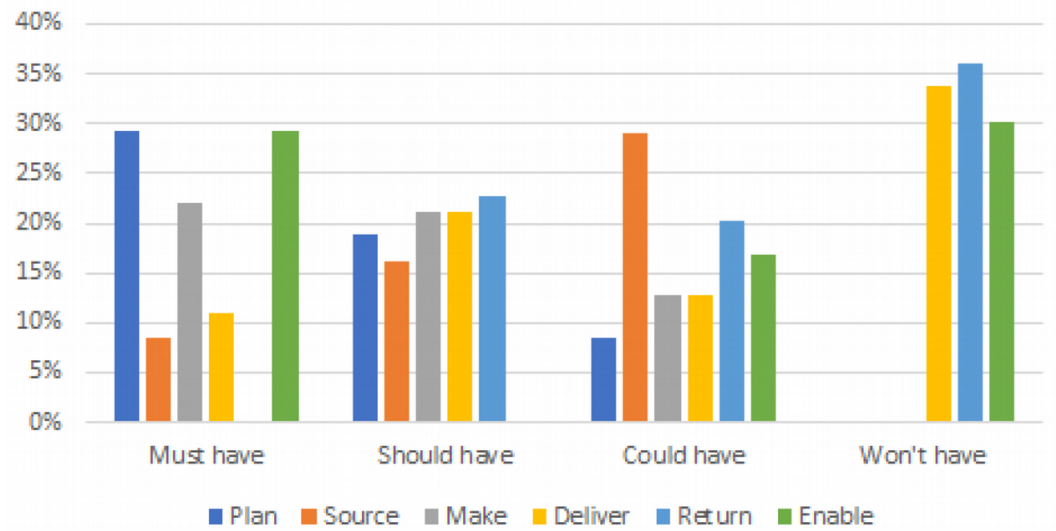

Figure 7. Analysis of prioritised metrics by process

\subsection{Discussion}

The MoSCoW prioritisation results in Figure 3 align with the experience of focus group participants regarding the COVID-19 pandemic in the airline catering supply chain. Performance metrics capture the effectiveness of the supply chain to the effect of uncertainties presented by the COVID-19 pandemic appeared to have recognised in the prioritisation. For example, 'external event response time' metric related to responsiveness attribute and enable 
process, cost-related metrics such as mitigation cost and direct labour cost, and upside, downside adaptability which are associated to agility attribute and make process. The least prioritised includes the percentage of item location accuracy due to the simplified catering procedure and the temporary alterations in packing plans, receive excess product cycle time, and capacity utilisation.

In Figure 6, the responsiveness attribute has the highest priority in the Must-have group whilst the reliability attribute has highest priority in the should-have, could-have, and won't-have groups. Reliability is generally considered crucially important (Jones, 2004), and it has the highest number of metrics in the developed airline catering performance metrics set. Hence, it has the highest rating in all the groups except Must-have, which is not surprising. Responsiveness came out top in the Must-have group primarily due to the significant uncertainties presented by the COVID-19 pandemic. An organisation needs to understand the uncertainties in their supply chain and supply chain responsiveness to achieve and sustain strategic alignment (Sundarakani et al., 2018). Time is critical in the airline catering logistics process (Jones, 2012), more so under high uncertainties, and it's important to respond to any catering related queries as quickly as possible. Catering issue resolution time must be quicker during an emergency period. There is an expectation for stricter adherence to the specific time slot allocated to each airline by airport management for flight operation during COVID-19 pandemic; hence, the catering service provider needs to be more responsive in managing the decatering and catering operations. The participants expressed a view that airlines appear to be more tolerant of the inflight meal and refreshments services during the COVID-19 pandemic period, hence the probable emergence of responsiveness attribute over reliability attribute in the Must-have group. The participants felt that during the COVID-19 pandemic, airlines are placing more emphasis on several other issues, including passengers' health and safety (Dube et al., 2021), in contrast to routine inflight meals and refreshments operations, although food safety remains appropriately prioritised (Jones, 2007). Interestingly the cost performance attribute does not appear in the won't-have group as each of its metrics is at least a could have.

There is a perception of an increase in performance measurements considerations for responsiveness, agility, and cost performance attribute, with the highest increase expressed for the responsiveness attribute (see, Figure 4). The agility performance attribute helps to measure the ability of airline catering service providers to manage airline disruptions (APICS, 2017). Disruptive events such as the COVID-19 pandemic give rise to the incidence of flight cancellations and sometimes airport closures, affecting airlines and passengers (Jones, 2004). The airline catering organisation should be flexible to provide enough refreshments for affected passengers at the airport and may be required to fulfil large supplementary order quantities for the next available service flight as a high number of passengers may be transferred from cancelled flights. Several airlines stopped their onboard meal service or diminished catering service extremely during COVID-19 (Amankwah-Amoah, 2020). Whilst the reduction in inflight service during the pandemic could be a safety measure, it can be argued that the meals service cuts by some airlines were fully or partly motivated by a cost-saving strategy. Therefore, there is an increased need for caterers to put additional measures to control catering operation costs and provide cost-effective inflight service. According to the focus group feedback, asset management attribute remains unchanged during the COVID-19 pandemic compared to other attributes as inventory of products and equipment has no implication on service stability in the relatively quiet catering operations. The organisation is also seeing very low capacity utilisation during the COVID-19 pandemic.

In Figure 7, both plan and enable processes have the greater preferences in the Must-have group, while the make process has the next higher preference. Plan process is highly regarded due to the uncertainty in airline operations during the COVID-19 outbreak; thus airline catering supply chain need to plan and respond quickly according to the airline catering requirements (Sundarakani et al., 2018). Participants perceive that the performance consideration associated with determining airline catering requirements and corrective actions to achieve catering service objectives becomes increasingly important during the COVID-19 pandemic than ever before. As the outbreak and uncertainties continue to dominate, many changes and restrictions are being introduced in arrival destinations day by day. Therefore, catering service providers also need to plan and react fast in delivering service according to the airline's decisions.

The focus group participants perceive that the enable process-related metrics as highly important for mitigating airline catering supply chain disruption during the COVID-19 pandemic. A lot of regulations, guidance, and safety 
precautions relating to COVID-19 is being updated frequently (Belhadi et al., 2021). This affects flight operations and schedule and causes flight cancellations and delays. Caterers need to come up with a mitigation plan for inflight catering services within a short timeframe (Lin, 2018). The focus group participants noted that the criticality of the enable process is more pronounced during the COVID-19 pandemic as it provides essential inputs and directions to support the planning and execution procedures of the airline catering supply chain during COVID-19 by maintaining and monitoring information, airline instruction, and compliance. Normally, due to the changes in aircraft and schedules, re-catering as per the service level changes and re-assembly work of catering containers becomes inevitable in airline catering operations (Law, 2011). Attention to the changes and their consequences is more evident during COVID-19 pandemic; hence, participants also prioritised some metrics relevant to make process.

As shown in Figure 5, there is an increase in performance measurements considerations for plan and enable processes and a decrease in source, make, deliver and return process related performance considerations, with the highest drop considered for source and return processes during the COVID-19 pandemic. Due to lower demand for airline catering orders, company X's purchasing activities has dropped significantly. It is not surprising that the relevance of source process-related performance measures has been highly decreased. The in-flight meal offering is needed to be altered to have a more simplified procedures and menu to comply with temporary health restrictions and social distancing rules (Pongpirul, Kaewpoungngam, Chotirosniramit \& Theprugsa, 2020). Pre-packaged meals are provided in disposable containers for some medium or high-risk routes. Passengers can use the same containers to store catering waste afterwards. Therefore, less catering wastage and catering equipment needed to be collected from return flights by the catering service provider and return sortation, recouping and recycling activities happens in the service centre on a much smaller scale compare to pre COVID-19 pandemic. This leads to a high decrease in the return process-related performance consideration during COVID-19. Although there is a perception of significant impact on make and deliver processes due to low volumes, the relevance of these process-related performance measures has only slightly decreased. Company $\mathrm{X}$ experiences the inevitable catering service amendments due to flight schedule changes or aircraft type changes. Such amendments can be quite frequent in uncertain times, and catering service providers should be flexible in completing any catering requirements changes within a given time (Hovora, 2001). Catering service providers may sometimes need to provide a different menu for all the passengers or completely reassemble and repack for different aircraft equipment types.

The participants in this case study mainly focused on operational efficiency in the development of the performance metrics for the airline catering supply chain. During the focus group discussion, the participants deliberated on challenges arising from the COVID-19 pandemic in the context of the airline catering supply chain. The challenges include those associated with food hygiene, safety measures (Dube et al., 2021), training issues, low passengers and flight operations, loss of revenue (Rimmer, 2020), greater uncertainties, frequent service requirements changes and inventory management chaos (Gunessee \& Subramanian, 2020), sustainability issues and performance measurement difficulties. Due to these challenges, airline catering will need to adapt performance management in line with COVID-19 measures. The participants believe that the performance metrics list in Table 4 would help address some of the challenges attributed to the COVID-19 pandemic, and they opined that the metrics prioritisation would guide the management regarding the focus areas during challenging times such as in the COVID-19 pandemic. There are several lessons learnt from the COVID-19 pandemic. There is a shift in performance metrics parameters; the entire airline catering industry has taken suitable measures to meet new requirements \& challenges posed by COVID-19. Absolutely as without performance metrics, catering service providers will not be able to meet the supply and demand needs of the airlines as and when circumstances change. Flexibility is a key principle required at the moment to maintain relationships and enhance trust in the airline catering supply chain. Airlines should also view their caterers, logistics service providers as part of their bubble and provide the support and care they require.

\section{Conclusions and Future Work}

COVID-19 challenges disrupted many industries, including the airline catering industry. The consequence of these challenges needs for airline catering supply chain to adapt their performance metrics. This paper has studied the adaptation of SCOR based performance metrics during the COVID-19 using the airline catering 
supply chain as a case study. The findings show that the airline catering supply chain needs to adapt their performance metrics, particularly those associated with responsiveness and reliability performance attributes. Less so are the performance metrics related to asset management efficiency. It is concluded prioritisation techniques, e.g. MoSCoW will help airline catering supply chain performance metrics considerations during an emergency situation such as the COVID-19 pandemic to help better manage their service deliveries and effectiveness in highly uncertain times. The research reported in this paper is based on a single case study and a limited number of participants, which impacts the generalisability of the results. Areas of future work include the extension and validation of the performance metrics development approach reported in this paper and seek to generalise a framework for adapting SCOR based performance metrics during the challenging period, such as those presented by the COVID-19 pandemic.

\section{Declaration of Conflicting Interests}

The authors declared no potential conflicts of interest with respect to the research, authorship, and/or publication of this article.

\section{Funding}

The authors received no financial support for the research, authorship, and/or publication of this article.

\section{References}

Adivar, B., Hüseyinoğlu, I.Ö.Y., \& Christopher, M. (2019). A quantitative performance management framework for assessing omnichannel retail supply chains. Journal of Retailing and Consumer Services, 48, 257-269.

https://doi.org/10.1016/j.jretconser.2019.02.024

Ahi, P., \& Searcy, C. (2015). An analysis of metrics used to measure performance in green and sustainable supply chains. Journal of Cleaner Production, 86, 360-377. https://doi.org/10.1016/j.jclepro.2014.08.005

Albers, S., \& Rundshagen, V. (2020). European airlines' strategic responses to the COVID-19 pandemic (January-May, 2020). Journal of Air Transport Management, 87, 101863. https://doi.org/10.1016/j.jairtraman.2020.101863

Amankwah-Amoah, J. (2020). Stepping up and stepping out of COVID-19: New challenges for environmental sustainability policies in the global airline industry. Journal of Cleaner Production, 271, 123000.

https://doi.org/10.1016/j.jclepro.2020.123000

APICS (2017). Supply Chain Operations Reference Model. Supply Chain Operations Management, 1-976. https://doi.org/10.1108/09576059710815716

Belhadi, A., Kamble, S., Jabbour, C.J.C., Gunasekaran, A., Ndubisi, N.O., \& Venkatesh, M. (2021). Manufacturing and service supply chain resilience to the COVID-19 outbreak: Lessons learned from the automobile and airline industries. Technological Forecasting and Social Change, 163, 120447. https://doi.org/10.1016/j.techfore.2020.120447

Beltman, S., Vosslamber, S.M., Molderink, A., \& Noordzij, M.L. (2016). Toward the Design of an Energy Consumption Feedback System. Ergonomics in Design, 24(3), 9-16. https://doi.org/10.1177/1064804615611283

Chinazzi, M., Davis, J.T., Ajelli, M., Gioannini, C., Litvinova, M., Merler, S. et al. (2020). The effect of travel restrictions on the spread of the 2019 novel coronavirus (2019-nCoV) outbreak. MedRxiv, 400, 395-400. https://doi.org/10.1101/2020.02.09.20021261

Chowdhury, P., Paul, S.K., Kaisar, S., \& Moktadir, M.A. (2021). COVID-19 pandemic related supply chain studies: A systematic review. Transportation Research Part E: Logistics and Transportation Review, 148, 102271. https://doi.org/10.1016/j.tre.2021.102271

Delipinar, G.E., \& Kocaoglu, B. (2016). Using SCOR Model to Gain Competitive Advantage: A Literature Review. Procedia - Social and Behavioral Sciences, 229, 398-406. https://doi.org/10.1016/j.sbspro.2016.07.150

Dube, K., \& Nhamo, G. (2019). Climate change and the aviation sector: A focus on the Victoria Falls tourism route. Environmental Development, 29, 5-15. https://doi.org/10.1016/j.envdev.2018.12.006 
Dube, K., Nhamo, G., \& Chikodzi, D. (2021). COVID-19 pandemic and prospects for recovery of the global aviation industry. Journal of Air Transport Management, 92, 102022. https://doi.org/10.1016/j.jairtraman.2021.102022

Elekdag, S., Muir, D., \& Wu, Y. (2015). Trade linkages, balance sheets, and spillovers: The Germany-Central European Supply Chain. Journal of Policy Modeling, 37(2), 374-387. https://doi.org/10.1016/j.jpolmod.2015.01.003

Fernandes, N. (2020). Economic effects of coronavirus outbreak (COVID-19) on the world economy. SSRN Electronic Journal, ISSN 1556-5068, Elsevier BV, 0-29. https://doi.org/10.2139/ssrn.3557504

Girjatovičs, A., Rizoto-Vidala-Pesoa, L.M., \& Kuzņecova, O. (2018). Implementation of SCOR Based Business Process Framework for Logistics and Supply Chain in Retail Company. Information Technology and Management Science, 21, 69-74. https://doi.org/10.7250/itms-2018-0011

Goel, R.K., Saunoris, J.W., \& Goel, S.S. (2021). Supply chain performance and economic growth: The impact of COVID-19 disruptions. Journal of Policy Modeling, 1-19. https://doi.org/10.1016/j.jpolmod.2021.01.003

Guan, D., Wang, D., Hallegatte, S., Davis, S.J., Huo, J., Li, S. et al. (2020). Global supply-chain effects of COVID-19 control measures. Nature Human Behaviour, 4(6), 577-587. https://doi.org/10.1038/s41562-020-0896-8

Gunessee, S., \& Subramanian, N. (2020). Ambiguity and its coping mechanisms in supply chains lessons from the Covid-19 pandemic and natural disasters. International Journal of Operations and Production Management, 40(7-8), 1201-1223. https://doi.org/10.1108/IJOPM-07-2019-0530

Hovora, J. (2001). Logistics in Onboard Services (Inflight Services) of Airlines. Tourism and Hospitality Research, 3(2), 177-180. https://doi.org/10.1177/146735840100300210

IATA (2018). LATA Forecast Predicts 8.2 billion Air Travelers in 2037. Available at: https://www.iata.org/en/pressroom/pr/2018-10-24-02/

IATA (2021). Reduced Losses but Continued Pain in 2021. Available at: https://www.iata.org/en/pressroom/pr/2021-04-21$\underline{01 /}$

Ivanov, D., \& Dolgui, A. (2020). Viability of intertwined supply networks: extending the supply chain resilience angles towards survivability. A position paper motivated by COVID-19 outbreak. International Journal of Production Research, 58(10), 2904-2915. https://doi.org/10.1080/00207543.2020.1750727

Ivanov, D., \& Dolgui, A. (2021). OR-methods for coping with the ripple effect in supply chains during COVID-19 pandemic: Managerial insights and research implications. International Journal of Production Economics, 232, 107921. https://doi.org/10.1016/j.ijpe.2020.107921

Jones, P. (2004). Flight Catering. Routledge.

Jones, P. (2007). Flight Catering. Food Service Technology, 4(2), 93-93. https://doi.org/10.1111/j.1471-5740.2004.00092.x

Jones, P. (2012). Flight Catering Management. The S AGE Handbook of Hospitality Management, 484-502. https://doi.org/10.4135/9781849200417.n23

King, T. (2001). Inflight Catering. Tourism and Hospitality Research, 3(2), 181-184. https://doi.org/10.1177/146735840100300211

Kochan, C.G., \& Nowicki, D.R. (2018). Supply chain resilience: a systematic literature review and typological framework. International Journal of Physical Distribution and Logistics Management, 48(8), 842-865. https://doi.org/10.1108/IJPDLM-02-2017-0099

Kottala, S.Y., \& Herbert, K. (2019). An empirical investigation of supply chain operations reference model practices and supply chain performance: Evidence from manufacturing sector. International Journal of Productivity and Performance Management, 69(9), 1925-1954. https://doi.org/10.1108/IJPPM-09-2018-0337

Kumar, M., Basu, P., \& Avittathur, B. (2018). Pricing and sourcing strategies for competing retailers in supply chains under disruption risk. European Journal of Operational Research, 265(2), 533-543.

https://doi.org/10.1016/j.ejor.2017.08.019 
Kusrini, E., Caneca, V.I., Helia, V.N., \& Miranda, S. (2019). Supply Chain Performance Measurement Usng Supply Chain Operation Reference (SCOR) 12.0 Model: A Case Study in A A Leather SME in Indonesia. IOP Conference Series: Materials Science and Engineering, 697(1), 0-10. https://doi.org/10.1088/1757-899X/697/1/012023

Law, K.M.Y. (2011). Airline catering service operation, schedule nervousness and collective efficacy on performance: Hong Kong evidence. Service Industries Journal, 31(6), 959-973.

https://doi.org/10.1080/02642060903079121

Lemghari, R., Okar, C., \& Sarsri, D. (2018). Benefits and limitations of the SCOR ${ }^{\circledR}$ model in automotive industries. MATEC Web of Conferences, 200. https://doi.org/10.1051/matecconf/201820000019

Lima-Junior, F.R., \& Carpinetti, L.C.R. (2020). An adaptive network-based fuzzy inference system to supply chain performance evaluation based on $\mathrm{SCOR}^{\circledR}$ metrics. Computers and Industrial Engineering, 139, 106191.

https://doi.org/10.1016/j.cie.2019.106191

Lin, W. (2018). Catering for flight: Rethinking aeromobility as logistics. Environment and Planning D: Society and Space, 36(4), 683-700. https://doi.org/10.1177/0263775817697977

Lu, Q., Goh, M., \& De Souza, R. (2016). A SCOR framework to measure logistics performance of humanitarian organizations. Journal of Humanitarian Logistics and Supply Chain Management, 6(2), 222-239.

https://doi.org/10.1108/JHLSCM-09-2015-0038

Luo, S., \& Tsang, K.P. (2020). China and World Output Impact of the Hubei Lockdown During the Coronavirus Outbreak. Contemporary Economic Policy, 38(4), 583-592. https://doi.org/10.1111/coep.12482

Martin, A., Markhvida, M., Hallegatte, S., \& Walsh, B. (2020). Socio-economic impacts of COVID-19 on household consumption and poverty. Economics of Disasters and Climate Change, 4, 453-479. https://doi.org/10.1007/s41885-020-00070-3

Mazareanu, E. (2020). Global airline catering services market size 2019-2026. Statista. https://www.statista.com/statistics/934663/global-airline-catering-services-market-size/

Nakamura, H., \& Managi, S. (2020). Airport risk of importation and exportation of the COVID-19 pandemic. Transport Policy, 96, 40-47. https://doi.org/10.1016/j.tranpol.2020.06.018

Pongpirul, K., Kaewpoungngam, K., Chotirosniramit, K., \& Theprugsa, S. (2020). Commercial airline protocol during COVID-19 pandemic: An experience of Thai Airways International. PLoS ONE, 15, 1-8. https://doi.org/10.1371/journal.pone.0237299

Pulidindi, K., \& Mukherjee, S. (2020). In-flight Catering Services Market Size - Global Share Report 2026. https://www.gminsights.com/industry-analysis/in-flight-catering-services-market

Qorri, A., Mujkić, Z., \& Kraslawski, A. (2018). A conceptual framework for measuring sustainability performance of supply chains. Journal of Cleaner Production, 189, 570-584. https://doi.org/10.1016/j.jclepro.2018.04.073

Remko, van H. (2020). Research opportunities for a more resilient post-COVID-19 supply chain - closing the gap between research findings and industry practice. International Journal of Operations and Production Management, 40(4), 341-355. https://doi.org/10.1108/IJOPM-03-2020-0165

Rimmer, P.J. (2020). Aviation and COVID- 19 pandemic: Towards the 'next normal. Journal of International Trade, Logistics and Law, 6, 119-136.

Salvatore, D. (2020). Growth and trade in the United States and the world economy: Overview. Journal of Policy Modeling, 42(4), 750-759. https://doi.org/10.1016/j.jpolmod.2020.03.001

Sellitto, M.A., Pereira, G.M., Borchardt, M., Da Silva, R.I., \& Viegas, C.V. (2015). A SCOR-based model for supply chain performance measurement: Application in the footwear industry. International Journal of Production Research, 53(16), 4917-4926. https://doi.org/10.1080/00207543.2015.1005251 
Sharma, R., Shishodia, A., Kamble, S., Gunasekaran, A., \& Belhadi, A. (2020). Agriculture supply chain risks and COVID-19: Mitigation strategies and implications for the practitioners. International Journal of Logistics Research and Applications, 0(0), 1-27. https://doi.org/10.1080/13675567.2020.1830049

Sobieralski, J.B. (2020). COVID-19 and airline employment: Insights from historical uncertainty shocks to the industry. Transportation Research Interdisciplinary Perspectives, 5, 100123. https://doi.org/10.1016/j.trip.2020.100123

Sundarakani, B., Abdul-Razzak, H., \& Manikandan, S. (2018). Creating a competitive advantage in the global flight catering supply chain: a case study using SCOR model. International Journal of Logistics Research and Applications, 21(5), 481-501. https://doi.org/10.1080/13675567.2018.1448767

Tufail, H., Qasim, I., Masood, M.F., Tanvir, S., \& Butt, W.H. (2019). Towards the selection of Optimum Requirements Prioritization Technique: A Comparative Analysis. 5th International Conference on Information Management, ICIM 2019 (227-231). https://doi.org/10.1109/INFOMAN.2019.8714709

Wu, J.T., Leung, K., \& Leung, G.M. (2020). Nowcasting and forecasting the potential domestic and international spread of the 2019-nCoV outbreak originating in Wuhan, China: a modelling study. The Lancet, 395(10225), 689-697. https://doi.org/10.1016/S0140-6736(20)30260-9

Journal of Industrial Engineering and Management, 2021 (www.jiem.org)

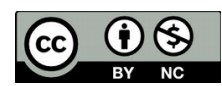

Article's contents are provided on an Attribution-Non Commercial 4.0 Creative commons International License. Readers are allowed to copy, distribute and communicate article's contents, provided the author's and Journal of Industrial Engineering and Management's names are included. It must not be used for commercial purposes. To see the complete license contents, please visit https://creativecommons.org/licenses/by-nc/4.0/. 